\title{
Hoaks; Teks dan Konteks dalam Al-Quran
}

\section{Danu Aris Setiyanto}

Institut Agama Islam Negeri (IAIN) Surakarta, Jawa Tengah, Indonesia danuaris07@yahoo.com

\begin{abstract}
The development of technology has been shifted human's way from the manual era to the digital era. Humans have been able to communicate without border and time. However, information in the modern era is not always true and many of them are false or hoaxes. Al Qur'an as a guide for humans has actually explained the hoax. Some words in the Al Qur'an illustrated the context of hoaxes such as ifk, kaẑaba, fitnah, khud'a, qaul al-zūr, buhtan, iftara, tahrif, and garur. In this paper, it will discuss the text of the hoax in the Al Qur'an in its text and textual verses when the verse is revealed. Furthermore, the context of the hoax in the Al Qur'an is explained in the context of the current issues with a semantic approach. This paper concludes that the meaning of the hoax in the Al Qur'an is in accordance with the recent context but only the media and problems are more complex. Furthermore, the Qur'an has provided solution to the issues of hoax such as checking the correctness of the data before sharing (Q. S Al-Hujurat: 6, Q. S Isra: 36), increasing the culture of literacy (Q. S Al-Qalam: 1 2), awareness of prejudice (Q.S Al-Hujurat: 12), and so on.
\end{abstract}

Keywords: hoax; al-Quran; text; textual; semantic.

\begin{abstract}
ABSTRAK
Perkembangan teknologi telah menggeser manusia dari era manual ke era digital. Manusia telah mampu berkomunikasi tanpa batas wilayah dan waktu. Namun, informasi pada era modern tidak selamanya benar dan banyak diantaranya disebut mengandung hoax, atau berita bohong. Al-Quran sebagai petunjuk manusia sebenarnya telah memberikan perhatian terhadap hoax. Beberapa kata dalam Al-Qur'an seperti ifk, kaẑaba, fitnah, khud'a, qaul al-zūr, buhtan, iftara, tahrif, garur telah mengilustrasikan konteks hoax. Paper ini membahas kosakata hoax dalam Al-Qur'an baik secara teks dan tekstualnya ketika ayat diturunkan. Selanjutnya, konteks hoax dalam Al-Qur'an tersebut ditarik ke dalam konteks masa kini dengan pendekatan semantik. Penulis berkesimpulan bahwa makna hoax dalam Al-Qur'an sesuai dengan konteks saat ini, hanya saja media dan permasalahannya lebih kompleks. Lebih dari itu, Al-Qur'an telah memberikan solusi menghadapi hoax, misalnya mengecek kebenaran data sebelum share (Q. S Al-Hujurat: 6, Q. S Isra: 36), budaya peningkatan literasi (Q. S Al-Qalam: 1-2), menjauhi prasangka (Q. S Al-Hujurat: 12), dan sebagainya.
\end{abstract}

Kata Kunci: hoaks; tafsir al-quran; tekstual; semantik

Corresponding Author

Name : Danu Aris Setiyanto

Email : danuaris07@yahoo.com 


\section{Pendahuluan}

Teknologi berkembang semakin pesat sesuai dengan perkembangan zaman (Koloay, 2016). Perkembangan teknologi menawarkan kemudahan dan mempercepat akses informasi. Media komunikasi semakin dibutuhkan karena dianggap mampu menyajikan peristiwaperistiwa aktual berskala nasional maupun internasional. Jadi, teknologi merupakan bagian penting dalam proses manusia dalam mengetahui, kemudian memahami, dan juga mengerti kondisi sekitar bahkan alam raya ini (Adhiarso, Utari, \& Slamet, 2017).

Kebebasan dalam bermedia sosial merupakan bagian dari dampak komunikasi global saat ini. Ini merupakan tantangan dan sekaligus peluang dalam masyarakat. Tak jarang kebebasan seringkali menimbulkan permasalahan karena digunakan untuk menebar fitnah dan kebohongan (hoaks). Hal ini menimbulkan opini publik yang bisa mengarahkan terjadinya kehebohan, ketidakpastian informasi, ketakutan, ancaman atau mungkin bentuk teror yang lain (Budiman, 2017). Keadaan lebih berbahaya terjadi apabila kegaduhan dalam media sosial tidak segera diselesaikan dan justru merambat menjadi kegaduhan realitas dalam masyarakat. Sentimen identitas kemudian muncul dengan hujatan dan kebencian. Akibatnya, apabila hal ini terjadi terus menerus maka dapat mengakibatkan dekontruksi kebinekaan yang terbentuk dari media sosial (Juliswara, 2017).

Sasaran efek negatif perkembangan era media sosial saat ini juga sangat luas diberbagai bidang kehidupan baik secara individul maupun kolektif, instansi pemerintahan maupun swasta. Hal ini dapat dilihat dalam bidang dakwah keislaman, transformasi muncul ketika para ulama mendatangi jamaah melalui media sosial dengan berbagai aplikasi (mulai dari Instagram, Twitter, WhatsApp group, telegram channel, dan lain sebagainya). Penggunaan media sosial harus diiringi kekuatan umat dalam memfilter, mengkualifikasi dan mengetahui hierarki keilmuan ulama atau ustadz dalam media sosial. Penyalahgunaan media bisa mengakibatkan relasi keislaman yang tidak ramah, berisi kemarahan, dan ketidakjelasan berita yang benar dan salah (hoaks). Fakta lain, Pemerintah Indonesia melalui Kementerian Komunikasi dan Informasi melakukan pengecekan dan pemblokiran 800.000 situs berkonten negatif dan mengandung kebohongan (hoaks) (Republika, 2017). Di bidang ekonomi, berita hoaks mengenai kebijakan kenaikan harga rokok yaitu Rp 50.000,00 per bungkus (Tempo, 2016). Di bidang militer, isu makar dilakukan oleh Purnawirawan TNI yang diilustrasikan seperti peristiwa G30S/PKI dan adanya rumor pencopotan Jabatan Panglima TNI (CNNIndonesia, 2017). Jadi, berita hoaks tersebar diberbagai kehidupan dan mengakibatkan banyak informasi yang tidak benar berkembang di masyarakat.

Salah satu efek negatif yang menonjol dalam media sosial adalah fenomena berita hoaks. Berita hoaks di Indonesia menjadi fenomenal sejak tahun 2016 dengan berbagai bentuk. Secara realitas, berita bohong diyakini kebenarannya oleh sebagian orang (Budiman, 2017). Masyarakat Telematika Indonesia merilis pada tanggal 13 Februari 2017 bahwa wabah hoaks telah menjadi masalah nasional antara lain perpecahan, instabilitas politik, dan gangguan keamanan yang berpotensi menghambat pembangunan nasional. Pemaparan survei menunjukkan bahwa masyarakat sebenarnya sudah mulai kritis terhadap berita hoaks karena telah terbiasa menerima berita hoaks (Mastel.id, 2017).

Terlepas dari berbagai isu di atas, Islam adalah agama yang komprehensif dan senantiasa konpatibel dengan dinamika zaman dan tempat. Oleh sebab itu, Al-Quran sebagai referensi agama Islam yang utama tentu juga dianggap mampu untuk menanggapi atau merespon realita dan problematika terkait perkembangan teknologi saat ini. Terlebih lagi terkait isu-isu berita bohong (hoaks) di era milineal ini. Perlu dipahami bahwa Al-Quran diposisiskan sebagai teks suci agama, sementara fenomena hoaks diposisikan sebagai isu yang berkembang saat ini. Dalam artikel ini, peneliti akan melihat apakah istilah hoaks sudah ada di dalam Al-Quran?; Apakah ada keselarasan makna Al-Qur'an dengan fenomena hoaks di media sosial saat ini?; Apa sajakah aspek sosiologis dan historis terkait fenomena sosial perilaku penyebaran berita hoaks dalam al-Quran? Apa saja antisipasi penyebaran berita hoaks dalam perspektif Al-Quran? 


\section{Metode Penelitian}

Dalam memahami Al-quran, terdapat dua dimensi dengan kerangka kerja yang berbeda. Pertama, dilihat dari asal usul keberadaannya, yaitu Tuhan. Kedua, dilihat dari fakta material yang merupakan bunyi tertentu ketika dibacakan dan dalam bentuk serangkaian huruf dalam bentuk tertulis. Yang pertama adalah teologis, sedangkan yang terakhir adalah linguistik atau sastra sebagai hasil dari budaya (Wekke, Amiruddin, \& Firdaus, 2018). Dalam stusi ini, penulis menjelaskan dengan pendekatan semantic yang merupakan bagian dari linguistik. Pendekatan ini digunakan dalam interpetasi kontekstual teks Al-Qur'an yang terkait tentang pembahasan yaitu berita hoaks dengan langkah-langkah antara lain, yaitu: mengumpulkan sebuah kata tentang kabar atau berita bohong dalam berbagai konteks di dalam al-Qur'an, membandingkan dalam penggunaan, menghubungkan istilah yang menyerupai, menghubungkan satu sama lainnya, dan mengambil kesimpulan.

Penelitian ini merupakan kajian pustaka yang membahas tentang hoaks. Peneliti menelaah dan memfokuskan kepada kajian berdasarkan teks-teks yang ada di dalam AlQur'an. Sedangkan untuk memahami teks tersebut, peneliti membaca tafsir-tafsir ayat dan referensi lain untuk menjelaskan secara lebih rinci. Beberapa referensi yang digunakan di antaranya adalah jurnal, majalah, buku, kamus, dan internet. Metode yang digunakan penulis adalah metode interpretasi. Penggunaan metode ini fokus pada penggalian makna yang terkait tentang hoaks atau berita bohong. Adapun pendekatan yang digunakan adalah metode tematik dengan membahas tema yang telah ditetapkan. Dengan demikian, pemahaman terhadap permasalahan lebih komprehensif dan penanggulangan terhadap hoaks dalam setiap bidang kehidupan manusia lebih bisa disikapi.

\section{Diskursus Al-Qur'an Tentang Hoaks 3.1. Hoaks}

Hoaks dalam An English-Indonesian Dictionary yang ditulis oleh John M. Ecols dan Hassan Shadily memiliki arti cerita bohong, olok-olokan (Ecols \& Shadily, 1997). Sedangkan dalam Cambridge Dictionary, hoaks adalah perencanaan untuk menipu seseorang atau tipuan (dictionary.cambridge.org). Dalam Oxford Dictonary disebutkan bahwa hoaks adalah a humorous or malicious deception (tipuan lucu atau tipuan yang jahat) (oxforddictionaries.com). Adapun kata lain yang semakna dengan hoaks adalah berita bohong, fitnah, ataupun yang sejenisnya (Pakpahan, 2017).

Hoaks dianggap sangat berbahaya karena menyebarkan informasi yang menyesatkan (Chen, Yong, \& Ishak, 2014). Pemberian informasi bertujuan hanya untuk menipu dan merekayasa pembaca untuk dapat mempercayai sebuah berita. Sementara, pembuat berita mengetahui bahwa berita tersebut adalah kebohongan atau berita palsu. Akibatnya, pembaca kadang hanya menerima dan membenarkan berita hoaks walaupun terkadang tidak masuk akal.

Dalam level nasional, berita hoaks berakibat adanya disintegrasi atau perpecahan baik sosial politik, suku, agama, dan ras. Dalam pemarapan yang disampaikan oleh Mastel bahwa hoaks yang sering diterima adalah bidang sosial politik mencapai 91 kasus (80\%), hoaks SARA diurutan berikutnya 88 kasus (60\%), isu kesehatan 41 kasus (20\%), makanan dan minuman $(32,60 \%)$, Penipuan keuangan $(24,50 \%)$, IPTEK $(23,70 \%)$, berita duka $(18,80 \%)$, candaan $(17,60 \%)$, bencana alam $(10,30)$, lalu lintas (4\%) (Pakpahan, 2017). Jadi,, hoaks membentuk berita bohong di beragam bidang untuk tujuan perpecahan masyarakat

\subsection{Istilah Kabar dalam Al-Qur'an}

Sebelum membahas persoalan hoaks, maka lebih baik mengurai beberapa informasi yang bermakna berita dalam Al-Qur'an. Istilah bermakna berita di dalam Al-Qur'an yaitu: An-Naba, Khabar, Hadits, Basyara-Busyro-Bisyarah. Berikut merupakan rincian penjelasan dari kata-kata yang tersebut sebagai upaya memberikan ilustrasi dasar tentang istilah kabar dalam Al-Qur'an.

Kata Naba dalam Al-Quran dapat ditemukan dalam Q. S An-Naba: 1-2, Q. S Ali Imran: 44; Q. S Hud: 49; Q. S Yusuf 102. Kata نبأ (nabaa) dalam Lisan Al-Arab dan juga Mu'jamul 
wasit diartikan الخبر (Al-khabar), kabar atau berita. Dalam kamus Al-Munawir kata nabbaa (نبَّ) artinya memberitakan atau memberitahukan (Munawwir, 1984).

Untuk memperjelas maksud istilah ini, disebutkan dalam al-Qur'an Abasa: 1-2.

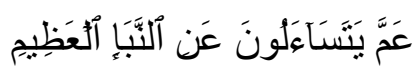

Artinya: Tentang apakah mereka saling bertanya-tanya? Tentang berita yang besar

Maksud dari kata النبأ dalam ayat ini dalam konteks berita yang besar terkait dengan hari kebangkitan. Dalam Tafsir Al-Wasith, ayat ini menegaskan bahwa Allah mengingkari kaum musyrikin Mekah dan segenap umat dipenjuru dunia atas pertanyaan mereka tentang hari kiamat. Allah bertanya alasan mereka bertanya tentang berita besar tersebut yaitu berita hari kebangkitan dari dalam kubur setelah kematian (Az-Zuaili, 2013).

Selanjutnya, kata khabar dalam Al-Qur'an dapat ditemukan dalam beberapa ayat misalnya Q. S Ali Imran: 154, Q.S At-Taubah: 16, Q. S Al-Maidah: 105, Q. S At-Taubah 94. Makna kata الخبر merupakan mufrad dari الأخبار yang dimaknai segala sesuatu yang dikabarkan atau yang diberitakan. Ada yang memaknai kata الخبر adalah apa yang dinukil atau diceritakan dari perkataan atau dari kitab. Sedangkan bentuk jamak kata الخبر (Alkhabar) adalah الأخبار dalam Kamus Munawir diartikan kabar, berita, dan keterangan (Munawwir, 1984).

Untuk memperjelas makna ini dalam Al-Qur'an dapat ditelaah misalnya dalam Q.S AtTaubah: 94

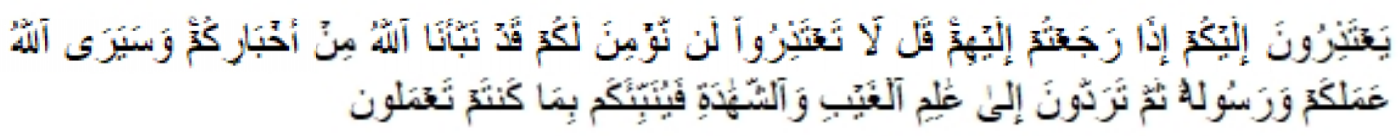

Artinya: Mereka (orang-orang munafik) mengemukakan 'uzurnya kepadamu, apabila kamu telah kembali kepada mereka (dari medan perang). Katakanlah: "Janganlah kamu mengemukakan 'uzur; kami tidak percaya lagi kepadamu, (karena) sesungguhnya Allah telah memberitahukan kepada kami beritamu yang sebenarnya. Dan Allah serta Rasul-Nya akan melihat pekerjaanmu, kemudian kamu dikembalikan kepada Yang mengetahui yang ghaib dan yang nyata, lalu Dia memberitahukan kepadamu apa yang telah kamu kerjakan.

Kata hadits dalam Lisan Al-Arab adalah bercerita atau kabar lama atau telah terjadi. Sedangkan kata basyar sendiri memiliki kata memberikan kabar, baik kabar kebaikan maupun keburukan (Ibn Manzur, 1999). Kata basyara dapat ditemukan misalnya dalam Q.S Ali Imran: 21

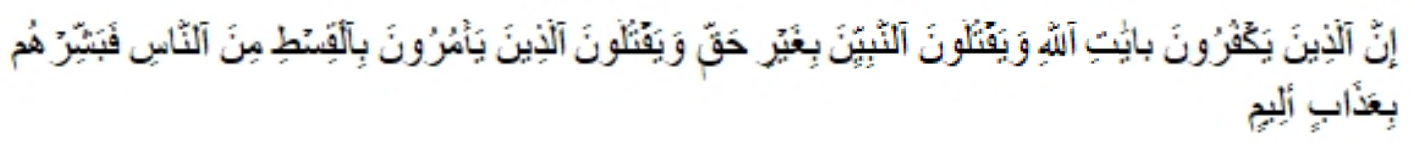

Artinya: Sesungguhnya orang-orang yang kafir kepada ayat-ayat Allah dan membunuh para nabi yang memang tak dibenarkan dan membunuh orang-orang yang menyuruh manusia berbuat adil, maka gembirakanlah mereka bahwa mereka akan menerima siksa yg pedih.

Dalam Tafsir Ibnu Katsir, dijelaskan bahwa konteks ayat ini menjelaskan perbuatan orang Yahudi yang dianggap taklid buta terhadap nenek moyangnya. Orang Yahudi juga dianggap bersalah karena tidak menunjukkan sikap ketidaksetujuan atas perbuatan nenek moyang, membunuh para Nabi dan hukama (Orang-orang bijak). Oleh karena itu, mereka kemudian diberikan basyara yaitu berita, kabar tentang azab yang pedih. Ayat ini bermaksud peringatan pada orang Yahudi atas perbuatan kejam yang mereka lakukan (Kementerian Agama, 2010).

\subsection{Istilah Hoaks dalam Al-Quran}

Istilah semakna hoaks dalam Al-Quran terdapat beberapa istilah yang bisa ditemukan. Beberapa istilah tersebut adalah ifk, kaẑaba, fitnah, khud'a, qaul al-zūr, buhtan, iftara, tahrif, dan garur. Beberapa kata ini memiliki kesamaan makna hoaks sebagaimana fakta 
sosial di masyarakat modern saat ini. Kata-kata tersebut sangat banyak (baik kalimat aslinya maupun turunannya) terdapat di dalam ayat-ayat Al-Quran. Namun dalam makalah ini, penulis hanya mengkaji beberapa ayat Al-Qur'an. Walaupun demikian, diharapkan ayat-ayat yang dijelaskan dapat menjadi referensi dan gambaran awal kajiankajian yang lebih terperinci.

Istilah ifk (kata bentuk) dan turunannya dalam Al-Quran disebutkan 22 kali. Delapan diantaranya disebutkan dengan ifk. Beberapa ayat tersebut antara lain dalam Q.S An Nur: 11-12, Al-Furqan: 4, Q. S Saba': 43, Q.S Al-Ahqaf: 11 dan 28, Q.S Al-Ankabut: 17, Q.S Ash-Shafat: 86 dan 151. Ada beberapa perbedaan penggunaan kata bentuk ifk dan dengan kata yang sama asal dengan ifk menurut Idna A. Idris, berimplikasi pada perbedaan makna. Penggunaan ifk secara asli merujuk pada pembawa dusta atau kebohongan yaitu kaum muslimin yang berpaling dari kebenaran atau melakukan dusta. Sedangkan penggunaan kata turunan ifk lebih cenderung ditekankan bahwa pelaku perkataan bohong adalah orang-orang kafir (Idris, 2018).

Beberapa makna ifk di dalam Al-Qur'an antara lain, yaitu memalingkan atau membalikan sesuatu, dusta, memalingkan dari yang benar ke yang salah, berita bohong dan lainnya. Salah satu ayat yang ada istilah ifk disebutkan di dalam Q. S An-Nur: 11-12. Dalam tafsir Al-Maturidi kata ifk diartikan sebagai kebohongan (الكنب) (Al Maturidi, 2005). Sedangkan dalam tafsir Ibnu Katsir, kata ifk bermakna dusta dan fitnah. Jadi, kata ifk bermakna hoaks dalam konteks berita bohong yang berkembang di masyarakat (Ibnu Katsir, 1994).

Dalam Eksiklopedi Al-Quran sebagaimana dikutip oleh Idnan Idris disebutkan bahwa ayat ini diturunkan karena adanya peristiwa Siti Aisyah yang tertinggal dalam rombongan saat perjalanan ke Madinah. Ketika itu Aisyah mencari kalung yang jatuh sewaktu memenuhi hajatnya dan para pembawa tandu yang membawa Aisyah mengira bahwa Aisyah sudah ada di dalam tandu. Saat Aisyah kembali, rombongan telah melanjutkan perjalanan. Dia kemudian memutuskan untuk menunggu di tempat semula dan tertidur. Secara bersamaan, salah seorang sahabat yang bernama Safwan bin Mu'aththal Al Sulami adz-Dzakwani juga tertinggal dari rombongan. Selanjutnya dia menemukan Siti Aisyah dan mengawal Aisyah pulang. Informasi tersebut kemudian didengar oleh salah seorang munafik yang berpura-pura baik di sisi Nabi Muhammad, yaitu Abdullah bin Ubay. Abdullah bin Ubay menyebarkan berita bohong bahwa Aisyah telah berbuat maksiat dengan Safwan. Allah menurukan kedua ayat ini untuk mejelaskan. Keluarga Rasulullah terselamatkan dari kehancuran akibat ulah tuduhan orang munafik (Idris, 2018). Dalam tafsir Ibnu Katsir dijelaskan bahwa yang paling berperan dalam penyebaran kebohongan tersebut adalah Abdullah bin Ubay bin Salul. Namun ada juga beberapa nama lain yang dihukum, yaitu Hassan bin Tsabit, Mitsah bin Utsasah, dan Hamnah bin Jahsy (Ibn Katsir, 2008).

Selanjutnya, kata hoaks dalam Al-Qur'an diidentikkan dengan kata kazaba (كنب). Dalam Ensiklopedia Al-Qur'an: Kajian Pustaka sebagaimana dikutip oleh Idnan Idris dijelaskan bahwa kata كنب dengan berbagai bentuknya terulang hingga 266 kali. Dari sekian pengulangan tersebut dapat dibedakan maknanya dengan beberapa bentuk yaitu dari sisi pelaku kebohongan, hal-hal yang dilakukan oleh seseorang atau kelompok yang berdusta, dan berdasarkan objek yang diingkari atau yang didustakan (Idris, 2018).

Pelaku pembohongan atau dusta dalam Al-Quran terdiri dari 3 golongan, yaitu orang kafir, munafik, dan sesat. Menurut Al-Qur'an, hal-hal yang dilakukan orang yang berdusta yaitu berdusta kepada Allah (Q. S Al Mukminun: 90), bersumpah bohong yang bertujuan memecah belah orang mukmin (Q. S At Taubah: 107), mengadakan kebohongan dan tidak beriman kepada ayat-ayat Allah (Q. S An-Nahl: 105 dan Q. S An-Nur: 13), mendengarkan ajakan syetan (Q. S Asy-Syuara': 223), mengajak berbuat kebohongan dan mengikuti mereka (Q. S Al-Ankabut: 12), berbuat syirik dan mengatakan Allah memiliki anak (Q. S As Shafat: 152), tidak menempati janji (Q.S Hasyr: 8), dan orang yang mau berjuang apabila ada yang menyenangkan dan menolak perjuangan yang menyusahkan (Q. S At-Taubah: 42). Jadi, Al-Qur'an menjelaskan karakteristik orang yang berdusta atau penyebar hoaks. 
Sedangkan kata kaẑaba (كذب) dengan segala bentuknya di dalam Al-Qur'an sebanyak 165 kali. Beberapa hal objek dari kata kaẑżaba (كتب) adalah ayat-ayat Allah (Q. S Al An'am: 21), siksa Tuhan (Q.S Sajdah: 20), Rasul-rasul Allah (Q. S Qaf: 14), perjumpaan dengan Allah (Q. S Al-An'am: 31), kebenaran Ilahi (Q. S Al-Ankabut: 18), kebajikan (Q. S Al-Lail: 9), ajaran agama (Q. S Al-Maun: 1), kebenaran metafisik (Q.S Yunus: 39), kitab-kitab suci (Q. S Ghafir: 70), dan hari kebangkitan (Q. S Al-Furqan: 11).

Dalam Q.S Al-Maun: 1, disebutkan bahwa:

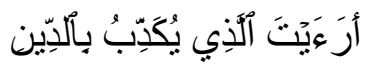

Artinya: Tahukah kamu (orang) yang mendustakan agama?

Dalam tafsir Ibnu Katsir, kata sialah mendustakan. Dalam konteks ayat tersebut dijelaskan bahwa Allah bertanya kepada Nabi Muhammad tentang pendusta agama (Ibn Katsir, 2008).

Selanjutnya, istilah hoaks dalam Al-Quran juga identik dengan kata fitnah (فتن). Kata fitnah dan segala bentuknya disebutkan sebanyak 60 kali dalam 33 surat. Quraish Shihab dalam Ensiklopedia Al-Qur'an: Kajian Kosakata mengartikan beberapa kata fitnah diantaranya adalah orang-orang yang enggan bertobat dari tindakan menzalimi atau menganiaya kaum muslimin (Q. S Al-Buruj: 10), membakar secara mutlak (Q. S AlBaqarah: 191), "siksaan" atau "hukuman" (Q. S Al-Anfal: 25).

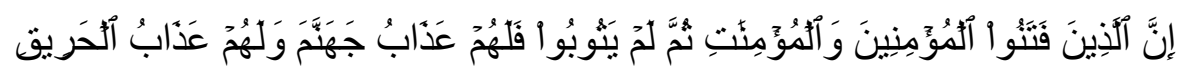

Artinya: Sesungguhnya orang-orang yang mendatangkan cobaan kepada orang-orang yang mukmin laki-laki dan perempuan kemudian mereka tidak bertaubat, maka bagi mereka azab Jahannam dan bagi mereka azab (neraka) yang membakar.

Istilah hoaks di dalam Al-Quran juga identik dengan kata khuda' (خدع). Kata khuda' (خدع) dapat diartikan memalingkan orang lain dari apa yang ada dihadapannnya dengan menampakkan sesuatu yang berbeda dari isi hatinya. Kata ini misalnya terdapat dalam Q. S Al-Baqarah: 9.

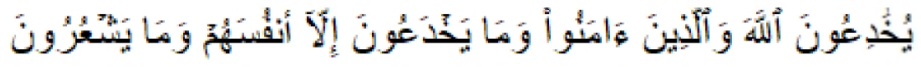

Artinya: Mereka hendak menipu Allah dan orang-orang yang beriman, padahal mereka hanya menipu dirinya sendiri sedang mereka tidak sadar.

Pengertian خدا خ dalam tafsir Al-Azhar yang ditulis oleh Hamka adalah dengan mulut yang manis, kecindan yang murah, berlagak seperti orang jujur, berpura-pura beriman, fasih dalam berkata-kata, dihias dengan firman Tuhan, sabda rasul supaya dia bersungguhsungguh. Sementara dalam Al-Qur'an dan Tafsirnya versi Kementerian Agama kata adalah menipu. Konteks kata tersebut fokus pada orang munafik yang menipu Allah, Rasul-Nya dan orang mukmin dengan memperlihatkan iman, kasih sayang, dan menyembunyikan permusuhan batin. Mereka bergaul dengan kaum muslimin untuk memata-matai, menyebarkan permusuhan dan fitnah untuk melemahkan barisan kaum muslimin.

Selanjutnya juga ada istilah qaul al-zūr (قول الزور). Kata tersebut terdapat dalam Al-Qur'an, misalnya dalam Q. S Al-Hajj ayat 30.

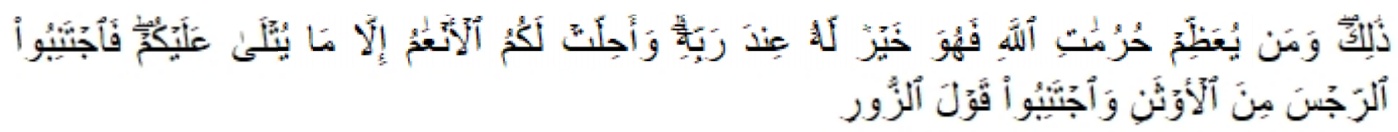

Artinya: Demikianlah (perintah Allah). Dan barangsiapa mengagungkan apa-apa yang terhormat di sisi Allah maka itu adalah lebih baik baginya di sisi Tuhannya. Dan telah dihalalkan bagi kamu semua binatang ternak, terkecuali yang diterangkan kepadamu keharamannya, maka jauhilah olehmu berhala-berhala yang najis itu dan jauhilah perkataan-perkataan dusta. 
Dalam tafsir Hamka dijelaskan bahwa makna qaul al-zūr dalam ayat tersebut adalah sesuatu yang keluar dari mulut berupa kata-kata omong kosong. Sementara itu, Ibnu Katsir menjelaskan bahwa makna qaul al-zūr dalam ayat tersebut adalah perkataan dusta dan sumpah palsu (Ibn Katsir, 2008).

Selanjutnya ada istilah buhtan (بهتي). Kata buhtan (بهتن) disebutkan enam kali dalam AlQur'an yaitu dalam Q. S An-Nur: 16, Q. S Al-Mumtahanah: 12, Q. S An Nisa: 20, 112, 156, dan Q. S Al-Ahzab; 58. Selain itu, ada juga dalam fi'il madi satu kali dalam surat AlBaqarah: 258 dan dalam fi'il mudari juga satu kali dalam Q. S Al-Anbiya: 40.

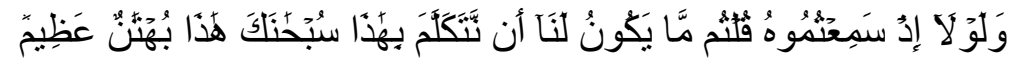

Artinya: Dan mengapa kamu tidak berkata, diwaktu mendengar berita bohong itu: "Sekali-kali tidaklah pantas bagi kita memperkatakan ini, Maha Suci Engkau (Ya Tuhan kami), ini adalah dusta yang besar".

Kata hoaks juga identik dengan kata Iftarah (افتره) dalam Al-Quran. Beberapa makna kata tersebut adalah memotong dengan tujuan merusak, kebohongan, syirik, dan zalim. Beberapa ayat yang menggunakan istilah ini adalah Q.S Sajdah: 3, dan Q.S Al-An'am: 144. Dalam Q. S Al-An'am misalnya:

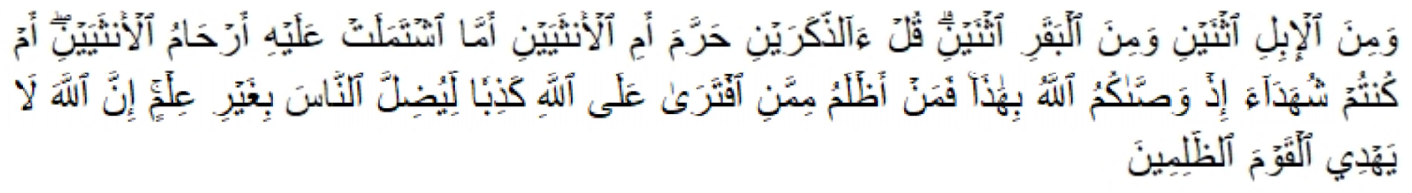

Artinya: dan sepasang dari unta dan sepasang dari lembu. Katakanlah: "Apakah dua yang jantan yang diharamkan ataukah dua yang betina, ataukah yang ada dalam kandungan dua betinanya? Apakah kamu menyaksikan diwaktu Allah menetapkan ini bagimu? Maka siapakah yang lebih zalim daripada orang-orang yang membuat-buat dusta terhadap Allah untuk menyesatkan manusia tanpa pengetahuan?" Sesungguhnya Allah tidak memberi petunjuk kepada orang-orang yang zalim.

Kata iftara dalam ayat ini identik dengan makna kedustaan, dan kedustaan merupakan sebuah kezaliman yang besar (Ibn Katsir, 2001).

Istilah selanjutnya yang disetarakan dengan hoaks dalam Al-Qur'an adalah tahrif (تحرف). Kata ini dapat ditemukan dalam beberapa ayat Al-Quran seperti dalam Q. S Al-Hajj: 11, Q.S Al-Baqarah: 75, dan Q.S Al-Maidah : 13, 41. Misalnya kita telaah Q.S Al: Baqarah ayat 75.

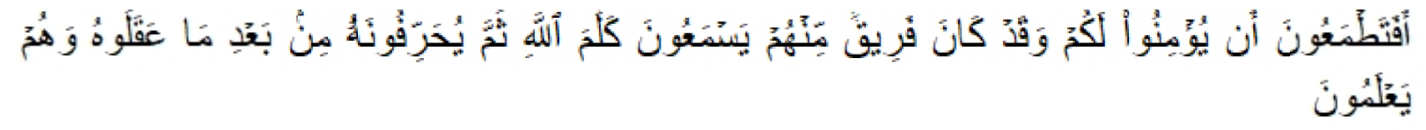

Artinya: Apakah kamu masih mengharapkan mereka akan percaya kepadamu, padahal segolongan dari mereka mendengar firman Allah, lalu mereka mengubahnya setelah mereka memahaminya, sedang mereka mengetahui?

Dalam Q.S Al-Baqarah ayat 75 di atas, makna harrifu tersebut adalah menafsirkan secara lain, mengubah ayat atau maksud (Basyir, Haidar, Muslim, \& Isma'il, 2016; Hamka, 2015), mengganti ayat, memutarbalikan isi, dan menyembunyikan (Kementerian Agama, 2010). Konteks ayat ini dalam tafsir Al-Azhar adalah mengingatkan bahwa kaum Yahudi tidak perlu diharapkan masuk Islam. Hal ini disebabkan karena Yahudi bersikap harrifu yaitu biasa mengubah ayat atau maksud ayat dan menafsirkan lain sejak zaman Nabi Musa (Hamka, 2015). Dalam tafsir Ibnu Katsir dijelaskan bahwa kalangan Ulama Yahudi mendengar kemudian mengubah dan menyembunyikan ayat dengan penuh kesadaran setelah memahami ayat tersebut terutama ayat-ayat yang terkait dengan sifat Nabi Muhammad SAW (Ibn Katsir, 2001).

Sedangkan kata yang sepandan dengan hoaks dalam Al-Quran yang terakhir adalah garur (غرر). Kata garur (غرر) dengan segala bentuknya disebutkan sebanyak 27 kali, 15 kali diantaranya dalam bentuk kata kerja baik madi maupun mudari, dan 12 kali dalam bentuk kata benda. Kata garur beberapa kali disebutkan dalam Al-Qur'an dengan subjek yang berbeda-beda. Pelaku garur dalam Al-Quran adalah orang-orang munafik (Q. S Al-Anfal; 
49), orang-orang kafir (Q. S Al-Anfal: 70 dan 130; Q.S Ghafir: 4, Q. S Al-Jatsiyah: 35, Q. S Al-Mulk), setan (Q. S An-Nisa: 120, Q. S Al-An'am: 112, Q. S Al-A'raf: 22, Q. S Al-Isra': 64, Q. S Luqman: 33, Q. S Fathir; 5), orang zalim (Q. S Fathir: 40), dan orang Yahudi (Q. S Ali Imran: 24) (Idris, 2018).

Untuk mewakili kata garra bisa diambil dalam Q. S Al-Anfal: 49.

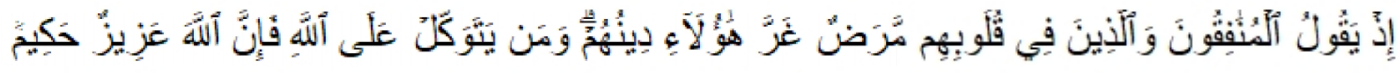

Artinya: "Ingatlah), ketika orang-orang munafik dan orang-orang yang ada penyakit di dalam hatinya berkata: "Mereka itu (orang-orang mukmin) ditipu oleh agamanya". (Allah berfirman): "Barangsiapa yang bertawakkal kepada Allah, maka sesungguhnya Allah Maha Perkasa lagi Maha Bijaksana".

Makna kata garra dalam ayat di atas terdapat beberapa pemahaman, yaitu ditipu (Hamka, 2015; Ibn Katsir, 2008) dan teperdaya (Basyir et al., 2016). Konteks ayat ini turun ketika perang Badar berkecamuk. Ketika pertemuan orang kafir dan orang muslimin saling mendekat, Allah kemudian menjadikan kaum muslimin berjumlah sedikit dimata kaum musyrikin. Kondisi yang demikian menjadikan kaum musyrikin mengatakan bahwa kaum muslimin telah tertipu dengan agama mereka, artinya mereka kaum musyrikin menyangka dapat mengalahkan dengan mudah kaum muslimin saat itu tanpa kesulitan sedikit pun (Ibn Katsir, 2008).

\section{Hasil Penelitian: Fenomena dan Kontekstual Hoaks dalam Kisah Al-Quran}

Al-Quran telah mengabadikan beberapa fenomena historis tentang peristiwa hoaks. Beberapa fenomena hoaks yang ada di dalam Al-Qur'an diantaranya telah disebutkan pada makalah ini. Beberapa fakta historis hoaks dapat ditemukan pada kisah nabi di dalam AlQur'an. Pertama, saat Iblis menggoda Nabi Adam A. S dan Siti Hawa hingga mereka berdua melanggar larangan Allah dan dikeluarkan dari surga. Kedua, kisah Siti Maryam dituduh berzina saat mengandung Nabi Isa A. S. Ketiga, Fir'an pernah menyebarkan berita hoaks bahwa Musa A. S adalah tukang sihir. Keempat, kisah Nabi Muhammad yang juga korban hoaks disebut sebagai tukang sihir dan bahkan mengatakan Al-Qur'an adalah hoaks. Beberapa kisah dalam Al-Qur'an sudah disebutkan dalam subbab sebelumnya. Seperti hoaks yang menimpa Aisyah dengan tuduhan perzinaan, kemudian diklarifikasi dalam Q.S An-Nur ayat 11-12. Jadi, peristiwa hoaks dijelaskan dalam Al-Quran yang dapat ditemukan pada kisah-kisah nabi.

Fenomena hoaks yang berkembang dalam masyarakat milineal tidak lepas dari pengaruh perkembangan teknologi. Inilah yang kemudian menimbulkan karakter masyarakat menjadi suka bertukar informasi. Pertukaran informasi didukung oleh media atau alat komunikasi yang cepat atau yang disebut dengan media sosial. Kemudahan akses informasi menjadi sarana mudah untuk menyebarkan hoaks dalam masyarakat dengan berbagai motifnya. Kondisi demikian tentu tidak sama dengan apa yang terjadi di dalam AlQur-an terutama media komunikasi penyebar hoaks. Namun, pada prinsipnya hoaks merupakan berita bohong yang selalu menggunakan media massa sesuai dengan konteks zamannya masing-masing.

Makalah ini membahas bagaimana konteks hoaks muncul dalam kehidupan sebagai fakta sosial. Hoaks berdampak pada berbagai bidang seperti agama, sosial, politik, dan lain sebagainya. Pembahasan difokuskan pada bidang agama dan politik yang ada dalam konteks Al-Quran dan di Indonesia.

Dalam lingkup agama, perilaku penyebar berita hoaks merupakan fenomena yang sudah membudaya dikalangan kafir dan munafik sejak lama. Penyebaran berita hoaks merupakan senjata dan alat yang dianggap ampuh untuk menghadapi kaum mukmin. Kesalahan yang dilakukan kaum mukminin juga tidak luput dari hoaks yang beredar dan propaganda yang kadang berujung peperangan. Hal tersebut juga dijumpai para Nabi dengan kaum kafir dan munafik. Dalam surat Q. S An-Nisa': 140 terdapat konteks pembicaraan dikalangan orangorang kafir (di dalamnya termasuk Yahudi dan Nasrani) yang menentang dakwah Rasulullah. Mereka berupaya membangun opini publik di berbagai forum dengan cara 
menyebarkan berita hoaks. Tujuannya adalah menjelek-jelekan dan mengolok-ngolok ayatayat Allah dan menentang dakwah Rasulullah SAW.

Dalam konteks saat ini, hoaks dalam bidang agama dianggap akan mengakibatkan intoleransi dan pecahnya persatuan dan kesatuan bangsa (Ratnasari, 2017). Beberapa tema hoaks dalam agama yang sering muncul misalnya Ahmadiyah atau Syiah, pelecehan agama, pengrusakan persaudaraan sesama umat muslim (ukhuwah Islamiyah), isu LGBT, komunisme, dan kristenisasi. Selain itu, isu-isu agama juga selalu dikaitkan dengan isuisu lain seperti politik, ekonomi, sosial dan lain sebagainya.

Selanjutnya, hoaks dalam bidang politik sangat sering terjadi di Indonesia. Hal ini disebabkan karena kontestasi politik yang sangat tinggi di musim politik Indonesia, misalnya berita bohong terkait kedatangan 500 orang penduduk Cina ke Indonesia untuk mendukung Ahok. Polisi akan memeriksa Amien Rais, dan lain sebagainya karena adanya arahan presiden untuk memilih Ahok. Hoaks dibidang politik mengangkat beberapa nama yang biasa terjadi di masa politik.

Motif kemunculan berita hoaks bervariasi berdasarkan pada bidang berita bohong yang disampaikan ke publik. Dalam Q. S Ali Imran: 70-71 disebutkan bahwa hoaks disebarluaskan karena ingin menutupi kebenaran yang ada dalam Taurat dan Injil. Ahlul Kitab dalam ayat tersebut membuat perkataan yang mereka buat-buat sendiri dengan membuat takwil yang rusak kemudian menyembunyikan kebenaran Muhammad SAW. Sehingga ini bisa disebut sebagai pelecehan terhadap agama karena agama menjadi sumber ketidakjelasan berita atau informasi.

Pada perkembangan di era milenial, hoaks dalam agama berkaitan erat dengan berbagai isu. Dalam konteks hukum, penyebaran hoaks dalam agama dapat menjadikan orang menjadi terpidana dan dikenai sanksi hukuman. Selain itu, hoaks dalam agama kemudian dianggap sebagai cara efektif melemahkan lawan-lawan politik, lawan pesaing usaha (contoh kasus produk haram atau halal), dan lain sebagainya.

Hoaks agama terjadi pada level internasional, misalnya saat ini selalu ramai dengan isu terorisme diberbagai negara. Terorisme kerap kali dianggap dan melekat kepada Islam. Pemahaman ini menjadi isu global dan menjadi pola pikir masyarakat umum bahwa terorisme selalu dilakukan oleh orang Islam. Sehingga kemudian muncul Islamophobia atau ketakutan terhadap segala sesuatu yang terkait Islam. Padahal, dalam fakta historiografi yang memunculkan Islamophibia, membatasi ruang gerak dan meredam dakwah Islam dilakukan oleh kaum kafir dan kaum munafik. Upaya yang dibangun dalam konteks tersebut adalah mendorong persepsi masyarakat (public opinion) dengan cara penyebaran berita hoaks yang berkelanjutan dan sistematis (Idris, 2018).

Berita hoaks juga erat hubungannya dalam dunia perpolitikan yang disebutkan dalam Al-Quran Q. S Al-Baqarah: 109 yang sebenarnya menggambarkan kegoyahan eksistensi kaum Yahudi maupun masyarakat asli Madinah lainnya karena kedatangan Nabi Muhammad SAW. Rasullullah sejak awal kedatangan sebagai kaum muhajirin melihat adanya komunitas heterogen dalam struktur masyarakat Madinah. Kota Madinah saat itu dihuni oleh tiga kelompok besar, yaitu suku Aus, Khazraj, dan Yahudi. Suku Auz dan Khazraj adalah dua suku yang saling berselisih dan disebut sebagai kelompok Al-Anshar. Sedangkan kelompok Yahudi sendiri terdiri dari 3 kelompok, yaitu Bani Qainuqa, Bani Nadhir, dan Bani Quraizha. Keengganan Yahudi untuk memenuhi ajakan Rasul tersebut diungkapkan dalam Q. S Ali Imran: 70-71. Kesimpulan ayat tersebut, mereka berusaha menyesatkan, menyebarkan berita kebohongan kepada kaum mukminin dengan mengubah sekian ayat dari Kitab Taurat supaya mereka kembali kafir.

Kancah perpolitikan di Indonesia juga tidak pernah larut dari hoaks (Ismail, 2018). Kasus Ratna Sarumpaet yang masih dalam proses hukum menjadi bukti bahwa hoaks perpolitikan belum usai. Informasi terkait Abdul Somad yang mendukung salah satu calon presiden juga bagian penting dalam berita kebohongan yang ada di dalam publik. Begitu pula berita hoaks yang belum lama terjadi, yaitu adanya tujuh kontainer surat suara yang sudah tercoblos. Dalam konteks perpolitikan, hoaks dengan motif politik sangat terlihat jelas digunakan para penguasa contohnya ketika Presiden Amerika Serikat George W. Bush 
melakukan intervensi kepada Irak dengan tuduhan kepemilikan senjata massal. Namun, setelah Saddam Husain jatuh tuduhan tersebut dianggap tidak terbukti.

Al-Quran bukan kitab yang diam dalam menanggapi segala kasus hoaks dalam berbagai bentuk dan bidang. Sebagai Kitab Suci yang dianggap sebagai petunjuk bagi manusia, maka Al-Quran sebenarnya sudah memberikan arahan cara menghadapi berita hoaks. Beberapa tawaran menghadapi berita hoaks dalam Al-Qur'an disebut dalam beberapa ayat Al-Qur'an.

Pertama, Al-Quran memberikan solusi bahwa setiap berita haruslah dipastikan kebenarannya. Kebenaran sumber berita harus diteliti dari siapa dan apa isi beritanya. Hal ini menjadi kewajiban untuk diteliti terutama untuk sumber berita yang dianggap dari orang fasik. Berita yang diterima tidak langsung dibagikan di media sosial tanpa ada klarifikasi. Kedua, Al-Qur'an memerintahkan untuk menahan diri untuk mempercayai berita yang tidak berdasarkan ilmu pengetahuan yang tepat. Selain itu, yang ketiga dalam Al-Quran disebutkan untuk menjauhi prasangka yang buruk sebagaimana disebutkan dalam Q. S Al-Hujurat: 12. Usaha lain yang bisa dilakukan adalah adanya pembinaan dalam tubuh umat islam, peningkatan kemampuan literasi, dan menyatakan perang terhadap berita hoaks (Idris, 2018).

Tata cara komunikasi di era modern idealnya tetap harus berdasarkan kepada asas memberikan manfaat kepada orang lain, kejujuran, menghindari ucapan kotor dan berkata positif. Pada sisi lain, penerima berita hendaknya selalu selektif dan mengecek validitas berita. Al-Quran mengajarkan sikap kritik namun juga bijak dalam menerima setiap berita dalam kehidupan. Hal ini tentu berlaku pula dalam bermedia sosial dan juga mengingat bahaya hoaks yang dapat menyebabkan ketegangan, perpecahan, bahkan menimbulkan kekerasan. Penyebar berita hoaks bisa dirugikan karena adanya pelanggaran hukum tentang informasi dan transaksi elektronik. Kasus penyebaran berita hoaks di Indonesia diatur dalam UU No. 19 Tahun 2016. Sedangkan pada level nasional, hoaks yang terus menggerus tanpa ditindaklanjuti oleh pemerintah akan merusak integrasi bangsa dan memunculkan pembodohan masyarakat.

\section{Kesimpulan}

Teks Al-Quran telah berperan penting dalam distribusi memperkaya teks dan konteks tentang berita hoaks. Istilah hoaks yang disebut merujuk pada berita bohong, olok-olokan, fitnah, dan sejenisnya. Dalam Al-Qur-an, istilah kabar memiliki beberapa versi seperti anNaba, khabar, badits, dan basyara-busyro-bisyarah. Sedangkan kata hoaks dalam Al-Quran disebutkan dalam beberap istilah misalnya ifk, kaẑaba, fitnah, khud'a, qaul al-zūr, buhtan, iftara, tahrif, dan garur.

Konteks berita hoaks telah menggambarkan bahwa hoaks yang ada saat ini bukanlah yang pertama. Penyebaran berita hoaks telah ada sejak manusia pertama dan terus ada hingga di masa Nabi Muhammad SAW hingga saat ini. Al-Qur'an menceritakan bahwa setan memberitakan kebohongan kepada Nabi Adam hingga dia dan Siti Hawa keluar dari surga. Kebohongan atau hoaks selalu mengiringi para Nabi dalam berdakwah. Di masa Nabi Muhammad, perjalanan Nabi dengan Aisyah ke Madinah muncul fitnah adanya tuduhan atau berita bohong yang diabadikan dalam Al-Qur'an.

Berbagai kosakata dan kisah tentang hoaks dalam Al-Qur'an sebenarnya memberikan makna hoaks sesuai massanya masing-masing. Konteks di era milenial sebenarnya tidak mengubah makna hoaks dalam kitab suci tersebut. Perkembangan digital hanya memainkan peran dalam perbedaan media dan permasalahan yang lebih kompleks. Berita hoaks disebarluaskan dalam media sosial yang lebih bervariasi tanpa harus tatap muka. Berbagai aplikasi seperti Whatssapp, Instagram, Facebook, Line, Twitter, dan lain sebagainya merupakan media dalam mempercepat penyebaran berita hoaks. Kebohongan atau hoaks yang disampaikan pun sangat bervariasi diberbagai bidang, dari permasalahan agama, politik, ekonomi, hukum, dan lain sebagainya. 


\section{Daftar Pustaka}

Adhiarso, D. S., Utari, P., \& Slamet, Y. (2017). Pemberitaan Hoax di Media Online Ditinjau dari Konstruksi Berita dan Respon Netizen. Jurnal Ilmu Komunikasi, 15(3), 215-225.

Al Maturidi, A. I. A. M. (2005). Takwilu Ahlu Sunnah Tafsir Al Maturidi. Beirut: Darul Kitab Ilmiah.

Az-Zuaili, W. (2013). Tafsir Al-Wasith. Jakarta: Gema Insani Press.

Basyir, H., Haidar, H., Muslim, M., \& Isma'il, A. A. (2016). Tafsir Muyassar; Memahami alQur'an dengan Terjemahan dan Penafsiran Paling Mudah. Jakarta: Darul Haq.

Budiman, A. (2017). Berita Bohong (Hoax) di Media Sosial dan Pembentukan Opini Publik. Majalah Info Singkat Pemerintahan Dalam Negeri, IX(1), 17-20.

Chen, Y. Y., Yong, S.-P., \& Ishak, A. (2014). Email Hoax Detection System Using Levenshtein Distance Method. Journal of Computers, 9(2), 441-446. https://doi.org/10.4304/jcp.9.2.441-446

CNNIndonesia. (2017). Dituduh Makar, Jenderal Gatot Sebut Hoax dan "Orang Gila." Retrieved November 17, 2018, from https://www.cnnindonesia.com/nasional/20170422132925-20-209440/dituduhmakar-jenderal-gatot-sebut-hoax-dan-orang-gila

Ecols, J. M., \& Shadily, H. (1997). An English-Indonesian Dictionary (XXIII). Jakarta: Gramedia Pustaka Utama.

Hamka. (2015). Tafsir Al-Azhar diperkarya dengan Pendekatan Sejarah, Sosiologi, Tasawuf Ilmu Kalam, Sastra dan Psikologi. Jakarta: Gema Insani.

Ibn Katsir. (2008). Tafsir Ibn Katsir. Jakarta: Pustaka Ibnu As-Syafi'i.

Ibn Manzur. (1999). Lisanul Arab (XI). Beirut: Dar as-Sadir.

Ibnu Katsir. (1994). Lubabut Tafsir min Ibni Katsir. Kairo: Muassasah Dar al-Hilal.

Idris, I. (2018). Klarifikasi Al-Qur'an atas Berita Hoax. Jakarta: Quanta.

Ismail, F. (2018). Guru Besar UII, Kontroversi Isu Keagamaan di Tahun Politik.

Juliswara, V. (2017). Mengembangkan Model Literasi Media yang Berkebhinnekaan dalam Menganalisis Informasi Berita Palsu (Hoax) di Media Sosial. Jurnal Pemikiran Sosiologi, 4(2), 142-164. https://doi.org/10.22146/jps.v4i2.28586

Kementerian Agama. (2010). Al-Qur'an dan Tafsirnya (Edisi yang Disempurnakan). Jakarta: Departemen Agama RI.

Koloay, R. N. S. (2016). Perkembangan Hukum Indonesia Berkenaan dengan Teknologi Informasi dan Komunikasi. Jurnal Hukum Unsrat, 22(5), 16-27.

Mastel.id. (2017). Hasil Survey Wabah HOAX Nasional 2017. Retrieved November 17, 2018, from https://mastel.id/hasil-survey-wabah-hoax-nasional-2017/

Munawwir, A. W. (1984). Kamus Al-Munawwir Arab-Indonesia Terlengkap. Surabaya: Penerbit Pustaka Progressif.

Pakpahan, R. (2017). Analisis Fenomena Hoax Diberbagai Media Sosial dan Cara Menanggulangi Hoax. Konferensi Nasional Ilmu Sosial \& Teknologi, 1(1), 479-484.

Ratnasari, Y. (2017). Berita Hoax Menjadi Ancaman Toleransi di Yogyakarta.

Republika. (2017). Ada 800.000 Situs Penyebar Hoax di Indonesia. Retrieved November 17, 2018, https:/ /www.republika.co.id/berita/nasional/umum/17/12/12/p0uuby257-ada800000-situs-penyebar-hoax-di-indonesia

Tempo. (2016). Wacana Harga Rokok Rp 50 Ribu, GAPPRI: Itu Hoax. Retrieved November 17, 2018, from https://bisnis.tempo.co/read/797734/wacana-harga-rokok-rp-50ribu-gappri-itu-hoax

Wekke, I. S., Amiruddin, A. A., \& Firdaus, F. (2018). Nasr Hamid Abu Zayd and The Hermeneutical of Qur'an. Epistemé, 13(2), 483-507. https://doi.org/10.21274/epis.2018.13.1.483-507 